\title{
Molecular Detection of JCV in Urine and Blood Samples of Renal Transplant Patients in Khartoum State, Sudan
}

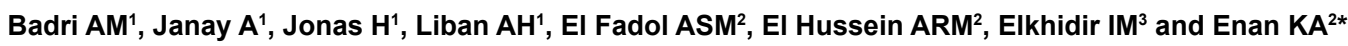

${ }^{1}$ Department of Medical Microbiology, Khartoum, Sudan

${ }^{2}$ Department of Virology Central Laboratory- The Minuteistry of Higher Education and Scientific Research, Khartoum, Sudan

${ }^{3}$ Department of Microbiology and Parasitology, University of Khartoum, Khartoum, Sudan

\begin{abstract}
Background: The present study aimed to investigate the infections of Polyomaviruses JCV (John Cunningham virus) in renal transplant recipients in Khartoum State in Sudan and to compare the results of the detection of JCV in urine and plasma.
\end{abstract}

Methodology: A total of 50 Plasma and 50 urine samples were collected randomly from renal transplant recipients attending Sudanese Renal Transplant society during period between January and February 2016. The samples were subjected to polymerase chain reaction (PCR) assay to detect the viral deoxyribonucleic acid (DNA).

Results: Among the 50 renal transplant patients the Polyomaviruses nucleic acid was detected in 24 plasma specimens (48\%) and only in 14 urine specimens (28\%) by using conventional PCR method.

Conclusion: JC Virus is related to clinical manifestations among renal transplant patients. The routine use of $\mathrm{PCR}$ on urine and plasma is a useful tool for the rapid and sensitive detection of $\mathrm{JC}$ virus in renal transplant recipient.

Keywords: JC polyomaviruses; Kidney transplant; PCR; DNA; Plasma; Urine; Sudan

\section{Introduction}

JC virus is classified as a member of the Polyomaviruses genus in the family Polyomaviridae which includes BK virus and SV40 [1].

They are non-enveloped icosahedral DNA viruses with genomes that are $5 \mathrm{~kb}$ in size. The genome is divided into 3 functional regions; the early region which encodes for 2 non-structural proteins, the large and small tumor antigens; the late region which encodes the 3 viral capsid protiens.VP1, VP2 and VP3; and the third segment is the noncoding regulatory region. Polyomaviruses BKV and JCV share $72 \%$ DNA sequence homology and shares $\sim 70 \%$ homology with SV40 [1].

The designation JC refers to the initials of the first patient in whom this virus type was identified while the name polyoma indicates the ability of this organism to produce tumors in many different organs [1]. JCV can be divided into 14 subtypes that are associated with different human population groups. For example, types 3 and 6 are found in Africans, type7A in Southeast Asians, and types 1 and 4 in Europeans [2].

Although primary infection may occur somewhat later in childhood and about $75 \%$ of the population has antibody against the virus; lifelong persistence is established. In infected persons the virus is shed in urine sporadically throughout life and more frequently during pregnancy or immune suppression. JC virus can cause a lethal disease; progressive multi focal leukoencephalopathy (PML); that is a complication of advanced disseminuteated malignant conditions such as Hodgkin's disease or chronic lymphocytic leukemia. JCV may also accompany primary or secondary immunodeficiency syndrome especially AIDS, or following immunosuppression for organ transplantation [3].

The polymerase chain reaction (PCR) constitutes the greatest advance in molecular biology since the advent of recombinant DNA technology. It enables a single copy of any gene sequence to be amplified in vitro at least a million fold within few hours. Thus viral DNA extracted from a very small number of virions or infected cells can be amplified to the point where it makes direct identification of the virus, possible viral antigen, or viral genome can readily be identified using labeled probes in a hybridization assay [4].
The epidemiology of JCV transmission is not fully understood. The virus may have been detected in the tonsil stromal cells and viral transmission via the respiratory route has been hypothesized, the virus has also been detected in the gastro-intestinal tract and in the raw urban sewage suggesting a possible oral/fecal-transmission of JCV. Also the virus isolation in B-lymphocytes suggests the risk of transmission through blood and blood products. Kidney transplantation has become the treatment of choice for patients with end-stage renal disease (ESRD). This has resulted in continued growing number of patients living with a functioning kidney allograft [5].

General accounts of JCV infection in renal transplant recipients have been published and all agree that strict attention should be paid to monitoring JCV infection especially during the first 24 months posttransplantation [3]. In particular, infection by JCV has been observed in renal allograft recipients as both nephropathy and /or PML (but PML occurs rarely) were recorded and are typically associated with high levels of viral genome in cerebrospinal fluid [3]. "Hemorrhagic cystitis" also has been attributed, sometimes, to JCV infection [6,7]. The aim of this study was to compare between urine and plasma samples for JCV detection using PCR.

\section{Materials and Methods}

\section{Study participants}

We performed a cross-sectional study during February to March 2016 involving a group consisted of 50 renal transplant patients $(70 \%$ male and $30 \%$ female) who are under follow up by Sudanese renal

*Corresponding author: Khalid A Enan, International University of Africa Faculty of Medical Laboratory Sciences, Department of Medical Microbiology, Khartoum, Sudan, Tel: +249912651103; E-mail: Khalid.enan@gmail.com

Received November 23, 2016; Accepted December 10, 2016; Published December 18, 2016

Citation: Badri AM, Janay A, Jonas H, Liban AH, El Fadol ASM, et al. (2017) Molecular Detection of JCV in Urine and Blood Samples of Renal Transplant Patients in Khartoum State, Sudan. Mol Biol 6: 178. doi: 10.4172/2168-9547.1000178

Copyright: $\odot 2017$ Badri AM, et al. This is an open-access article distributed under the terms of the Creative Commons Attribution License, which permits unrestricted use, distribution, and reproduction in any medium, provided the original author and source are credited. 
Citation: Badri AM, Janay A, Jonas H, Liban AH, El Fadol ASM, et al. (2017) Molecular Detection of JCV in Urine and Blood Samples of Renal Transplant Patients in Khartoum State, Sudan. Mol Biol 6: 178. doi: 10.4172/2168-9547.1000178

Page 2 of 4

transplantation society in Khartoum State, Sudan. The patients' ages ranged from 4 months to 64 years old. The demographic data collected included age, gender, date of renal transplantation, and residence. Samples (urine and plasma) were collected from these patients and tested for the presence of JCV DNA using PCR in the Virology Department of Central Laboratory, Minuteistry of Higher Education and Technology, Khartoum, Sudan. Ethical approval of the study in accordance with the guidelines of the ethical considerations and was granted by the Central laboratory committee. Patients consent was obtained before the commencement of the study.

\section{Sample collection}

From each patient, the sample collection involved one urine sample $(10$ to $20 \mathrm{ml})$ collected in sterile urine containers and frozen at $-20^{\circ} \mathrm{C}$ until used and one blood sample (2 to $3 \mathrm{ml})$ collected in sterile EDTAblood containers. The blood samples were centrifuged at $3000 \mathrm{rpm}$ for $5 \mathrm{~min}$ and plasma were collected in new plain containers and frozen at $-20^{\circ} \mathrm{C}$ until used.

\section{DNA extraction}

Urine: DNA was extracted from $7 \mathrm{~mL}$ of the urine sample, by the Guanidine chloride extraction method [8-11]. The purified DNA was dissolved in $100 \mu \mathrm{l}$ of distilled water and stored at $-20^{\circ} \mathrm{C}$ until PCR process.

Plasma: DNA was extracted from $250 \mu \mathrm{l}$ of plasma sample, following SDS and Proteinase K extraction method [11]. The purified DNA was dissolved in $100 \mu \mathrm{TE}$ buffer and stored at $-20^{\circ} \mathrm{C}$ until tested by PCR.

\section{Semi-nested PCR assay to detect JCV DNA}

The semi nested PCR was carried out as described in [12] using three primers to amplify JCVT-antigen sequences as follows: \{3049-3069, 5'-TGGCCTGTAAAGTTCTAGGCA-3'\}; \{3229-3207, 5'-GCAGAG TCAAGGGATTTACCTTC-3'\} and \{3193-3171, 5’AGCAACCTTGATTGCTTAAGAGA\} [13].

Three primers display sequences that avoid annealing with Polyomaviruses other than JCV nucleotides. Each reaction was performed in $25 \mu \mathrm{l}$ volume containing $5 \mu \mathrm{l}$ master mix (Solis Bio dyne master mix), $1 \mu \mathrm{l}$ of each primer (1 and 2) for the first round and (1 and 3 ) for the second round, $7 \mu \mathrm{l}$ of DNA, and $11 \mu \mathrm{l}$ of distilled water. Reactions were performed using PCR machine Techno (Japan) under the following cycling conditions: $8 \mathrm{~min}$ at $95^{\circ} \mathrm{C}$ followed by 35 cycles of $30 \mathrm{~s}$ at $95^{\circ} \mathrm{C}, 30 \mathrm{~s}$ at $55^{\circ} \mathrm{C}$ and $30 \mathrm{~s}$ at $72^{\circ} \mathrm{C}$. A final elongation period of $7 \mathrm{~min}$ at $72^{\circ} \mathrm{C}$ was applied. $5 \mu \mathrm{l}$ of the PCR product was analyzed by gel electrophoresis in $2 \%$ Agarose, and stained with $0.15 \%$ Ethidium bromide and the product was visualized by using UV gel documentation system INGeNius Germany. The expected size of JCV DNA amplicon is $145 \mathrm{bp}$.

\section{Statistical analysis}

Collected data were analyzed using statistical package for social science (SPSS) Descriptive statistics (Frequency and Percentages) was performed and then plotted into pie charts. Cross tabulation for JCV detection in Urine and Plasma were undertaken. Student's T-test was used to test significance between selected parameters of the study. $\mathrm{P}$ value of $\leq 0.05$ was considered significant.

\section{Results}

The results on the detection of JCV from the plasma and urine samples of renal transplant patients are shown in Table 1. Of the fifty

\begin{tabular}{|c|c|c|c|}
\hline \multirow{2}{*}{ Sample type } & \multicolumn{2}{|c|}{ Frequency } & \multirow{2}{*}{ Positive \% } \\
\cline { 2 - 4 } & Positive & Negative & 48 \\
\hline Plasma & 24 & 26 & 28 \\
\hline Urine & 14 & 36 & 61.3 \\
\hline Total & 38 & 62 & \\
\hline
\end{tabular}

Table 1: Frequency of JCV detected in plasma and urine samples from renal transplant patients.

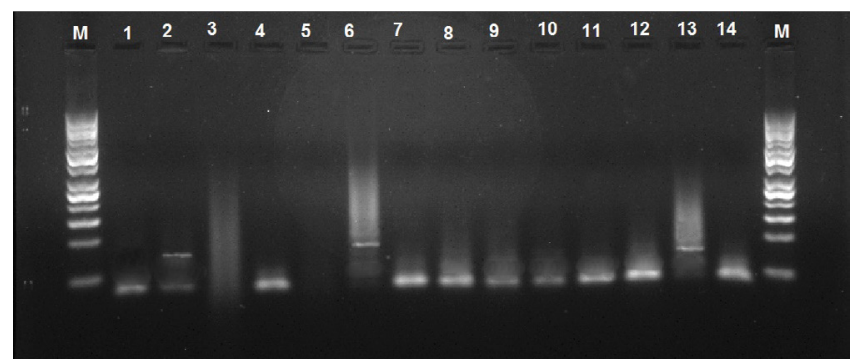

Figure 1: JCV DNA results (145 bp) on $2 \%$ agarose gel.

Lane M shows 100 bp DNA marker, lane 1 shows negative control, lane 2 shows positive control, lanes 6 and 13 show positive results and lanes $3,4,5$,

$7,8,9,10,11,12,14$ show negative results

\begin{tabular}{|c|c|c|c|c|}
\hline Technique & $\begin{array}{c}\text { PCR +ve } \\
\text { Plasma }\end{array}$ & $\begin{array}{c}\text { PCR -ve } \\
\text { Plasma }\end{array}$ & Total & $\begin{array}{c}\text { Agreement } \\
\text { (\%) }\end{array}$ \\
\hline PCR +ve Urine & 7 & 7 & 14 & \\
\cline { 1 - 3 } PCR -ve Urine & 17 & 19 & 36 & \multirow{2}{*}{52} \\
\hline Total & 24 & 26 & 50 & \\
\hline
\end{tabular}

Table 2: Cross tabulation of positive and negative PCR results of the plasma and urine samples (kappa correlation).

plasma samples analyzed $24(48 \%)$ were positive for JCV while of the fifty urine samples analyzed (28\%) were positive for JCV [14]. All positive PCR samples revealed abundant amplicon of $145 \mathrm{bp}$ indicative of the JCV genome (Figure 1). Comparison between PCR results of JCV from both plasma and urine samples showed that out of the 14 urine positive patients 7 were plasma positive and 7 were plasma negative while out of the 24 plasma positive patients 17 were negative by urine testing and 7 were positive. This revealed an overall agreement of $52 \%$ (26/50) (Table 2).

The results showed no correlation between Urine and Plasma samples positivity $(P>0.05)$. There was also no significant correlation between age, gender and duration of the transplantation and positivity of urine and plasma samples (Table 3).

\section{Discussion}

Several reports of JCV infection in renal transplant recipients have been published and it is recommended that strict attention should be paid monitoring JCV infection in these patients particularly during the first year of the transplantation [3].

There has been no study in Sudan regarding JCV reactivation in renal transplant recipients with asymptomatic nephropathy. Given the association of JCV reactivation with the use of immune suppressive therapies we undertook this present research to investigate whether JCV reactivation occurred in these patients [9].

In the current study the qualitative PCR procedure was used to detect JCV DNA in plasma and urine samples. Specimens were obtained from 50 renal transplant patients. The results showed the superiority of plasma samples (48\%) over urine samples (28\%) for the detection of JCV. This is considered unusual result for plasma samples. 


\begin{tabular}{|c|c|c|c|c|c|}
\hline $\begin{array}{l}\text { Sample } \\
\text { No. }\end{array}$ & Gender & Age & $\begin{array}{l}\text { Plasma } \\
\text { JCV }\end{array}$ & Urine JCV & $\begin{array}{c}\text { History of } \\
\text { kidney transplants }\end{array}$ \\
\hline 1 & Male & 4 month & Positive & Negative & 2016 \\
\hline 2 & Female & 4 month & Negative & Positive & 2016 \\
\hline 3 & Female & 58 years & Negative & Negative & 2015 \\
\hline 4 & Male & 48 years & Positive & Negative & 2004 \\
\hline 5 & Male & 1 year & Negative & Positive & 2015 \\
\hline 6 & Female & 44 years & Positive & Negative & 2015 \\
\hline 7 & Female & 10 years & Negative & Negative & 2015 \\
\hline 8 & Female & 1 year & Positive & Positive & 2015 \\
\hline 9 & Male & 48 years & Positive & Positive & 2007 \\
\hline 10 & Female & 47 years & Negative & Positive & 2014 \\
\hline 11 & Male & 22 years & Negative & Positive & 2015 \\
\hline 12 & Female & 19 years & Positive & Negative & 2015 \\
\hline 13 & Male & 2 month & Negative & Negative & 2016 \\
\hline 14 & Female & 4 month & Negative & Negative & 2016 \\
\hline 15 & Female & 4 month & Negative & Negative & 2016 \\
\hline 16 & Male & 18 years & Negative & Negative & 2015 \\
\hline 17 & Male & 1 year & Positive & Positive & 2015 \\
\hline 18 & Male & 65 years & Positive & Positive & 2013 \\
\hline 19 & Male & 36 years & Negative & Negative & 2015 \\
\hline 20 & Male & 4 month & Negative & Negative & 2016 \\
\hline 21 & Male & 4 month & Negative & Positive & 2016 \\
\hline 22 & Male & 17 years & Negative & Negative & 2015 \\
\hline 23 & Male & 25 years & Positive & Negative & 2015 \\
\hline 24 & Male & 49 years & Positive & Positive & 2015 \\
\hline 25 & Male & 25 years & Positive & Positive & 2012 \\
\hline 26 & Male & 26 years & Positive & Negative & 2016 \\
\hline 27 & Male & 22 years & Negative & Positive & 2015 \\
\hline 28 & Male & 1 year & Negative & Negative & 2015 \\
\hline 29 & Male & 46 years & Positive & Negative & 2015 \\
\hline 30 & Female & 10 years & Positive & Negative & 2011 \\
\hline 31 & Male & 35 years & Positive & Negative & 2015 \\
\hline 32 & Male & 4 month & Positive & Negative & 2016 \\
\hline 33 & Male & 55 years & Negative & Negative & 2013 \\
\hline 34 & Male & 45 years & Negative & Negative & 2007 \\
\hline 35 & Male & 4 month & Positive & Negative & 2016 \\
\hline 36 & Male & 60 years & Negative & Negative & 2008 \\
\hline 37 & Male & 2 month & Positive & Negative & 2016 \\
\hline 38 & Female & 22 years & Negative & Negative & 2012 \\
\hline 39 & Male & 24 years & Positive & Negative & 2014 \\
\hline 40 & Male & 63 years & Positive & Negative & 2015 \\
\hline 41 & Male & 1 year & Positive & Negative & 2015 \\
\hline 42 & Female & 26 years & Positive & Positive & 2013 \\
\hline 43 & Male & 29 years & Positive & Positive & 2015 \\
\hline 44 & Male & 54 years & Negative & Negative & 2015 \\
\hline 45 & Female & 34 years & Negative & Negative & 2016 \\
\hline 46 & Male & 51 years & Positive & Negative & 2006 \\
\hline 47 & Male & 22 years & Negative & Negative & 2015 \\
\hline 48 & Male & 23 years & Negative & Positive & 2004 \\
\hline 49 & Female & 10 years & Negative & Negative & 2016 \\
\hline 50 & Female & 4 month & Negative & Negative & 2016 \\
\hline
\end{tabular}

Table 3: Table for the different parameters.

Several researchers indicated: JCV in kidney biopsy tissue and/or urine within a range of $3.4 \%$ to $46 \%$ of kidney transplanted patients [1416]. Our results for urine samples are well within this range but our plasma samples results were much higher than those found by others. Thinks about on the identification of JCV viremia in renal transplant patients are clashing; Razonable et al. [17] distinguished JCV DNA in the blood of $7.6 \%$ of renal transplant patients amid the principal year post-transplant while different creators couldn't recognize JCV DNA in the blood of renal transplant and liver transplant patients [18], still some others have reported uncommon transient, and low viremia [19]. However in another study led on 20 patients, 25\% demonstrated JCV viremia [11]. Every one of these studies was completed by utilizing quantitative continuous PCR. In this study, the use of plasma samples rather than whole blood specimen to detect JCV DNA might have increased the sensitivity of JCV detection and could explain why current results are different from those of other studies. However, the reports that JCV viremia is more commonly detected among renal transplant recipients than viremia may be due to the fact the virions may enter the circulation through peri-tubular capillaries following tubular damage. Such patients could be at potential risk of developing JCV nephropathy, thus detection of JCV DNA by PCR in urine is currently concurrently used to detect viral replication in renal transplant patients. Detection of JCV DNA by PCR in plasma specimens is not efficient in patients with low viral replication in the urinary tract. For this reason JCV viremia is only used to confirm JCV after first screening urine [11].

Our findings showed that the virus may not need to enter blood following tubular damage and the detection by PCR in plasma may be used for screening. Our results could also suggest that plasma may be used to obtain an early diagnosis of patients at risk of JCV effects on kidney functions.

\section{Conclusion}

The presence of JCV was further documented among renal transplant patients in Sudan. The results of the present study indicated that urine sample and plasma can be used for PCR detection of JCV.

The routine use of PCR on urine and plasma in Sudan may be a useful tool for the rapid and sensitive detection of JCV in renal transplant recipients. Thus, establishment of this technique in the country may be of great value for monitoring renal transplant recipients who might be at possible risk for the development of JCV nephropathy.

\section{Funding}

This work is partially supported by central laboratory, Minuteistry of Science and Technology, Khartoum, Sudan.

\section{Acknowledgement}

The authors are grateful to Dr. Khalid Enan from central laboratory for fruitful discussions and advice. We are also thankful to U. Abdelaziz Atta and U Soad Alfd for helpful discussion on the molecular analysis. We acknowledge the Sudanese renal transplantation society for allowing us to collect the samples from patients. We are thankful to the central laboratory, Minuteistry of Science and Technology, Khartoum, Sudan for financial assistance.

\section{References}

1. Kwak EJ, Vilchez RA, Randhawa P, Shapiro R, Janet S, et al. (2002) Pathogenesis and management of polyoma virus infectiuon in transplant recipients. Clin Infect Dis 35:1081-1107.

2. Taheri S, Kafilzadeh F, Shafa M, Yaran M, Mortazavi M, et al. (2011) Comparison of polyoma virus (BK virus and JC viruses) viruria in renal transplant recipients with and without kidney dysfunction. J Res Med Sci 16: 916-922.

3. David OW, Frank JF (1994) Medical virology; Fourth Edition. Albuquerque, New Mexico, p: 303.

4. Delbue S, Ferraresso M (2012) JC polyoma virus infection in renal transplant patients. J Transplant Technol Res 2: 3.

5. Kayser FH, Bienz KA, Eckert J, Zangernagel RM (2005) Thieme Stuttgart; Flexbook Medical Microbiology, p: 415.

6. Eun JK, Regis AV, Randhawa P, Ron S, Janet S (2002) Pathogenesis and management of polyoma virus infection in transplant recipients. Clin Infect Dis 35: 1081-1107

7. Laura AS, Andrew R, Oliver GP, Edward CH (2006) JC virus evolution and its association with human populations. J Virol 9928-9933. 
Citation: Badri AM, Janay A, Jonas H, Liban AH, El Fadol ASM, et al. (2017) Molecular Detection of JCV in Urine and Blood Samples of Renal Transplant Patients in Khartoum State, Sudan. Mol Biol 6: 178. doi: 10.4172/2168-9547.1000178

8. Renzo B, Claudia V, Diana B, Guido M (2005) Kidney and urinary tract polyoma virus infection and distribution. Arch Pathol Lab Med 129: 69-73.

9. Serena D, Mariano F, Luciana G, Camilla C, Silvia C, et al. (2013) A review on JC virus infection in kidney transplant recipients. Hindawi Publishing Corporation Clinical and Developmental Immunology.

10. Ibrahim AH, Hisham NA, Yousif FH, Khalid AE, Isam ME (2016) Molecular characterization of polyoma viruses (BKV, JCV) in asymptomatic kidney recipients in Sudan. Am J Infect Dis M 4: 44-51.

11. Nishiguchi MK, DeSalle R Giribet G, Wheeler WC (2002) DNA isolation procedures techniques in molecular systematics and evolution, pp: 247-287.

12. Bofill MS, Pina S, Girones R (2000) Documenting the epidemiologic patterns of polyoma viruses in human populations by studying their presence in urban sewage. Appl Environ Microbiol 66: 238-245.

13. Jian PW, Zuo ZW, Yu SZ, Xia P, Xiang HY, et al. (2012) JC virus existence in Chinese gastrointestinal carcinomas. Oncol Lett 3: 1073-1078.

14. Husseiny MI, Anastasi B, Singer J, Lacey SF (2010) A comparative study of
Merkel cell, BK and JC polyomavirus infections in renal transplant recipients and healthy subjects. J Clin Virol 49: 137-140

15. Yin WY, Lu MC, Lee MC, Liu SC, Lin TY, et al. (2010) A correlation between polyoma virus $\mathrm{JC}$ virus quantification and genotypes in renal transplantation. Am J Surg 200: 53-58.

16. Hu JH, Zhao H, Huang YP et al. (2011) Opportunistic post transplantation virus infections in renal transplant recipients. Transplant Proc 43: 3715-3719.

17. Razonable RR, Brown RA, Humar A, Covington E, Alecock E, et al. (2005) A longitudinal molecular surveillance study of human polyoma virus viremia in heart, kidney, liver and pancreas transplant patients. J Infect Dis 192: 1349-1354.

18. Randhawa P, Baksh F, Aoki N, Tschirhart D, Finkelstein S (2001) JC virus infection in allograft kidneys; analysis by polymerase chain reaction and immunohistochemistry. Transplantation 71: 1300-1303.

19. Drachenberg $\mathrm{CB}$, Hirsch $\mathrm{HH}$, Papadimitriou JC (2007) Polyoma virus BK versus JC replication and nephropathy in renal transplant recipients: A prospective evaluation. Transplantation 84: 323-330.
This article was originally published in a special issue, Molecules involved in cell signaling pathways handled by Editor(s). Dr. Masood Alam Khan, Al-Qassim University, Saudi Arabia 